\title{
Bias and potential misinterpretations in the analysis of insects collected from human remains of archaeological interest
}

\author{
Stefano Vanin ${ }^{1,2} \cdot$ Morgan Azzoni $^{3} \cdot$ Giorgia Giordani $^{4} \cdot$ Maria Giovanna Belcastro ${ }^{3}$
}

Received: 29 March 2021 / Accepted: 5 October 2021 / Published online: 19 October 2021

(c) The Author(s) 2021, corrected publication 2022

\begin{abstract}
Insects collected from human remains are an important source of information about the peri- and postmortem events and they are the object of attention of two disciplines. Forensic entomology deals with insects collected from remains of forensic interest and funerary archaeoentomology with insects from archaeological contexts. In the collections of human remains (mummies, bones, etc.) belonging to museums or other institutions, insects can be found and can be used to make some interpretation about the past. This is possible only if the specialist is able to distinguish between the insects associated with the living subject or with the body decomposition and the pests colonizing the body stored in the collection. This paper, starting from the analysis of 42 human individuals belonging to three Italian osteological collections (Bologna, Parma, and Cagli), provides a working scheme to distinguish between "old" and museophagous insects in order to reduce the misinterpretations of the entomofauna associated with human remains.
\end{abstract}

Keywords Funerary archaeoentomology $\cdot$ Diptera $\cdot$ Coleoptera $\cdot$ Lepidoptera $\cdot$ Osteological collection $\cdot$ Anthropology

\section{Introduction}

The study of insects and other arthropods from archaeological contexts provides useful elements to better describe past scenarios and events, cultural traditions, environments and climates. Archaeoentomology is a multitopic discipline dealing with different subjects depending on the archaeological contexts and the kind of questions or hypotheses at which is requested to answer. For example, in the very interesting works of Forbes et al. (2020), the authors focalized their

Stefano Vanin

stefano.vanin@unige.it

1 Dipartimento Di Scienze Della Terra Dell'Ambiente E Della Vita (DISTAV), Università Di Genova, Corso Europa 26, 16132 Genova, Italy

2 National Research Council, Institute for the Study of Anthropic Impact and Sustainability in the Marine Environment (CNR-IAS), Via de Marini 6, 16149 Genova, Italy

3 Dipartimento Di Scienze Biologiche, Geologiche E Ambientali, Alma Mater Studiorum, Università Di Bologna, 40126 Bologna, Italy

4 Dipartimento Di Farmacia E Biotecnologie (FABIT), Alma Mater Studiorum, Università Di Bologna, 40126 Bologna, Italy attention on the reconstruction of climate in southwestern Alaska using beetle subfossil data, whereas in another study Forbes et al. (2010) were able to describe the domestic activities, including animal products and hay storage, house renovations, floor maintenance and trade in late nineteenth and early twentieth century Icelandic farmers.

In 1996, Jean Bernard Huchet suggested the possibility of using insects, as in forensic entomology, in funerary contexts of archaeological interest defining a new discipline: funerary archaeoentomology (Huchet, 1996). Since that day, several papers have been published allowing the reconstruction of funerary practices (Huchet and Greenberg 2010), war and fighting events (Huchet 2013a) and the hygienic conditions of past populations (Huchet and Greenberg 2010). Most of the studies focus their attention to South America and Europe (mainly France, Italy, Portugal, Spain, UK) archaeological sites but this kind of cluster can be ascribed to the distribution of the scientists dealing with this topic and their projects and not with the real presence of insects associated with the archaeological site. Moreover, it is worth mentioning that funerary archaeoentomology has been applied not only to human remains but also to animal carcasses when they have been used in funerary or religious rituals as for example as offerings (Giordani et al. 2020; Huchet et al. 2013). 
In general, the arthropods sampled from funerary contexts can be grouped into 6 categories:

1. Ectoparasites, insects and other arthropods associated with the living person or animal;

2. Insects associated with body and carrion decompositions and their predators and parasitoids;

3. Insects associated with the environments in which the body/carcass was located (here, we can include as well insects associated with the infestation of the wood of the coffin);

4. Insects associated with offerings;

5. Contaminations occurred in the past;

6. Cultural heritage and museum collection pests active in the past as well in the present.

The first four categories have been clearly described in the papers previously mentioned whereas only few works deal with the $5^{\text {th }}$ (Huchet $2013 \mathrm{~b}$ ) and the $6^{\text {th }}$ group is mainly the topic of biodeterioration and cultural heritage conservation literature (Manachini 2015).

The need of distinguishing between insects associated with the funerary material in the past and insects active nowadays is fundamental in the interpretation of the entomological evidence and in the design of pest control/management strategies for the preservation and conservation of the archaeological material. It is worth mentioning that the question is not trivial and in some cases it is not easy to solve due to the food preferences of some of these insects such as some members of the family Dermestidae and Curculionidae (Coleoptera) and Tineidae (Lepidoptera), able to colonize centuries-old samples (Halmschlager et al. 2007). The problem was raised for the first time by Panagiotakopulu (2003) analysing archaeological samples of different origin and nature (wheat, bread, meat, cartonnage mask) from the collection of the Egyptian Museum in Turin (Italy). In her paper, the author suggested use of $\mathrm{C}_{14}$ dating of individual specimens to resolve the particular cases where distinguishing between past specimens and nowadays contaminations is not easy to be solved. In addition, the issue from the point of view of the collection curator was discussed by Morrow et al. (2017) studying the entomofauna associated with the mummified body of the Blessed Antonio Patrizi (Central
Italy). In their paper, the authors mentioned the presence of muscid puparia belonging to the genus Hydrotaea Robineau-Desvoidy, 1830 and a desiccated and crushed moth in the family Tineidae. Despite confusing forensic with archaeological topics, the authors underline the importance of a proper analysis and identification of the entomological findings for the curatorial strategies and the archaeological reconstructions.

Due to the paucity of literature on this topic and due to the risk of interpretation errors, this paper aims to provide some tips to help in the understanding and interpretation of the insects' remains from archaeological and museum collections. In particular, the tested hypothesis was concerned with the possibility or not of distinguishing between initial insect colonizers of decomposing bodies and collection pests. The research is based on the analysis of bone remains from three Italian osteological collections.

\section{Material and methods}

The research of entomological specimens was carried out on human remains from the three modern (nineteenth to twentieth c.) documented (for sex and age) osteological collections of Bologna, Parma in Northern and Cagli in Central Italy and stored at the Museum of Anthropology (University of Bologna, Italy) (Belcastro et al. 2017).

The insect searching and sampling were carried out on 42 skulls (jugular foramen and fossa, carotid canal, orbital cavity, lacrimal fossa, nasal cavity, etc.) (Table 1), as well as, with a particular attention, on the hair and on the dry soft tissues still associated with some bones.

Specimens were observed and photographed using a Leica M205C stereomicroscope equipped with a Leica EC3 digital camera and the LAS software (Leica, Germany).

All the specimens are stored in dry condition in plastic vials in the Forensic Laboratory for Entomology and Archaeology, University of Genoa (FLEA) collection.

Identification was done using specific keys (Giordani et al. 2019; Peacock, 1993; Skidmore 1985; Smith 1986) and by comparison with identified specimens stored in collection.
Table 1 Number of human individuals and taxa collected per osteological collection

\begin{tabular}{llllllll}
\hline Collection & $\begin{array}{l}N \text { (human } \\
\text { individuals) }\end{array}$ & $\begin{array}{l}\text { Bodies with } \\
\text { insects }\end{array}$ & $\begin{array}{l}\text { Diptera } \\
\text { puparia }\end{array}$ & Coleoptera & Lepidoptera & Acarina & Total \\
\hline Bologna & 26 & 9 & 17 & 17 & - & 1 & $\mathbf{3 5}$ \\
Parma & 10 & 9 & - & 172 & - & & $\mathbf{1 7 2}$ \\
Cagli & 6 & 6 & 80 & 7 & 5 & 1 & $\mathbf{9 3}$ \\
Total & $\mathbf{4 2}$ & $\mathbf{2 4}$ & $\mathbf{9 7}$ & $\mathbf{1 9 6}$ & $\mathbf{5}$ & $\mathbf{2}$ & $\mathbf{3 0 0}$ \\
\hline
\end{tabular}




\section{Results}

The research of entomological specimens from the human remains reveals a different pattern of prevalence of insect on the bones (Table 1) ranging from the $35 \%$ of the Bologna's remains to the $100 \%$ of the Cagli's individuals. Parma collection has $90 \%$ of the human remains colonized by insects.

More interesting is that the composition of the entomological fauna showed a high component of exuviae of museophagous species not associated with the decomposition of the bodies per se. In fact, $64 \%$ of the specimens were Dermestidae exuviae (Fig. 1) that in the Parma collection represented $100 \%$ of the samples. All the Dermestidae specimens have been identified as belonging to the genera Attagenus Latreille, 1802 (species Attagenus pelio (Linnaeus, 1758)) and Anthrenus (Geoffroy, 1762). Only broken elytra of other four beetle specimens have been detected among the bones: two of them, from the Cagli collection, have been identified as belonging to a species in the genus Necrobia Olivier, 1800 (Cleridae), whereas the other two, potentially, to a species in the genus $\mathrm{Lyc}$ tus Fabricius, 1792 (Bostrichidae), are from the Bologna collection. Lepidoptera cocoons have been recorded only from Cagli collection and they have been identified as Trichophaga tapetzella (Linnaeus, 1758) (Tineidae).

If, from one hand, insects that colonized the bones during their storage in the collection belong to Dermestidae (Coleoptera) and to Tinaeidae (Lepidoptera), on the other hand the insects associated with the body colonization during the decomposition are mainly in the family Calliphoridae and Muscidae (Diptera) and Cleridae (Coleoptera). Their presence is documented by the findings of several puparia of the dipteran taxa (Fig. 2).

The Calliphoridae puparia fragments belong to the species Calliphora vicina Robineau-Desvoidy, 1830 and have been collected only from the Bologna's samples whereas the Muscidae specimens were identified as Hydrotaea capensis (Wiedemann, 1818) and a species in the genus Muscina Robineau-Desvoidy, 1830. They have been sampled from
Fig. 1 Exuviae belonging to Dermestidae species in lateral and dorsal views. A Anthrenus sp. and $\mathbf{B}$ Attagenus pelio (scale bar: $1 \mathrm{~mm}$ ). In Italy, Anthrenus verbasci (Linnaeus, 1767) is a common species in museum and private collections but for this taxon exuviae were identified only at the genus level

\section{A}
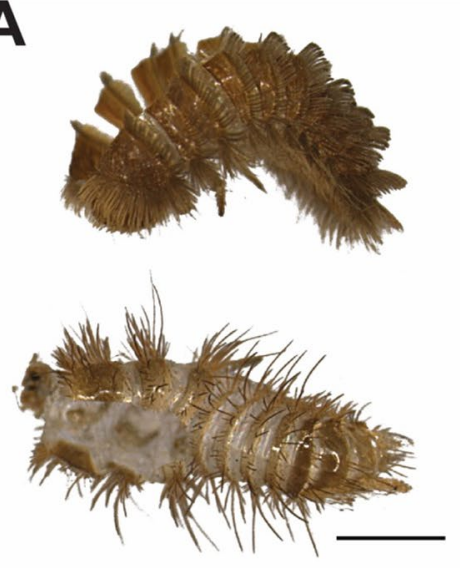

B
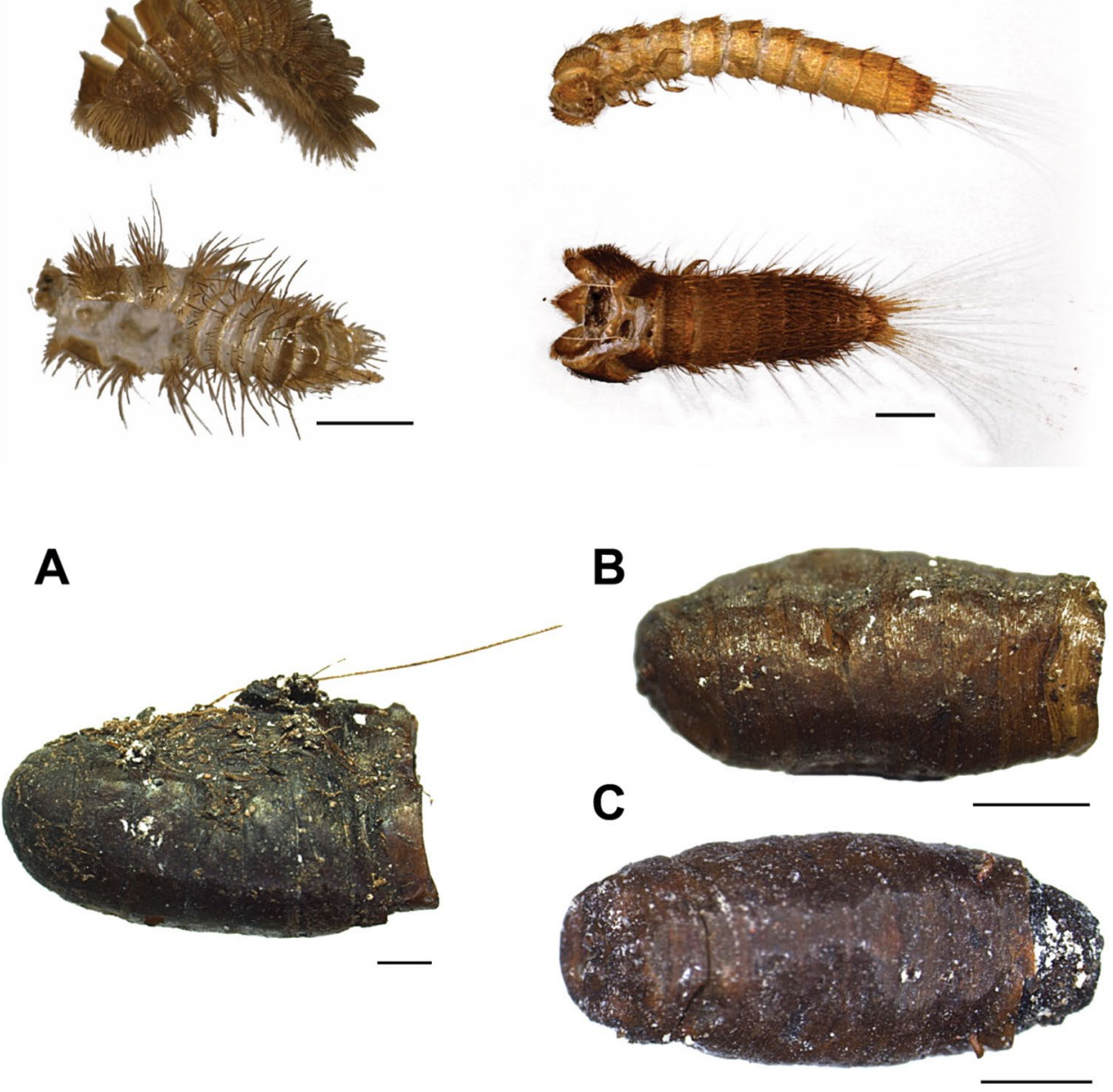

Fig. 2 Puparia of A Calliphoridae and B, C Muscidae (Hydrotaea capensis) in lateral and dorsal views (scale bar: $1 \mathrm{~mm}$ ) 
the Bologna and Cagli collections. In the last, they represent $86 \%$ of the entomological specimens.

The few mites recorded belong to the Oribatida order that is characterized by the well-sclerotized exoskeleton of its members. No further identification was performed on the specimens; however, from an ecological point of view, they could be related with the soil where the human remains had laid before their exhumation.

Puparia were collected from different skeletal regions but the majority were gathered from the skull, particularly from the orbital cavity, the nasal and lacrimal fossae, where larvae found sheltered and protected condition for pupariation. In contrast, despite being collected also from different skull districts, exuviae appear abundant on the hair still associated with the bone remains.

Some puparia are incomplete or partially destroyed whereas others show a matte colour, darker and opaquer, if compared with fresh samples (for comparison, see Giordani et al. (2019)). In addition, as shown in Fig. 2, exuviae appear in good conditions: they are complete or about complete and their hair (setae) are still present. No sign of biting or alteration due to the feeding activity of other organisms is detectable.

\section{Discussion}

It is of common knowledge that insects and other organisms can represent an important issue in the conservation of the cultural heritage, and for this reason several higher education institutions deliver modules on biodeterioration focusing on bacteria, fungi and invertebrate, as well as on birds and mammals, that can alter artworks and architectural structures not only with their feeding or nesting activities but also with their excrements. The aim of this paper is not to focus on them and to suggest eradication strategies or precautional measures for museal sample conservation but to provide some tips to distinguish between museophagous insects (MI) destroying the collections and the entomological samples (AI) useful from an archaeoentomological point of view. We start from the observation of the entomological findings on three Italian osteological collections.

In the case presented in this paper-that can be anyway considered enough representative of the average situationfragments of insects belonging to the two groups MI and AI have been found at the same time, on the same osteological samples. AI are composed mainly of Diptera puparia showing important alteration in their structure and colours, whereas MI are composed of exuviae of beetles in good state of preservation as highlighted by the quality and colour of their long setae. In addition, the thin cuticle of the exuviae does not show any sign of biting or consumption or any other mechanical or physical alteration.
Despite being part of the fauna able to colonize a body after the death, the genera Anthrenus and Attagenus are more related with very dry samples and they are commonly found on samples stored in museum collections (Vanin 2019).

In general, we suggest the following working scheme to distinguish between MI and AI despite good experience is needed and in case of interpretation of entomological findings from human remains from archaeological contexts and/or museum collections, an entomologist used to work with archaeological and nowadays carrion-feeding insect has to be involved.

\section{Succession waves}

After the death, a series of physical and (bio)chemical transformations occurs on a body depending on biotic and abiotic factors such as the presence of bacteria and other microorganisms, the humidity, the temperature and the presence/absence of oxygen. Insects are known for their ability of exploitation of any potential source of food and to colonize any environment. In the subaerial/terrestrial environment, insects evolved the ability of using the body in each phase of its decomposition as a source of food. Megnin in 1894 was the first scientist that described the order of arrival of the insects depending on the decomposition status and he recognised the dipterans in the family Calliphoridae, Muscidae and Sarcophagidae as the first body colonizers (Mégnin 1894; Smith 1986). Despite the original usage of the French words "escouades de la mort" to define the different insect communities that succeed each other on the body, this process is better described using the English form of "waves of colonization" indicating a continuous process with some species appearing on the body and then disappearing with the arrival of other species with overlapping of co-presence.

The order of arrival, depending on the phase of decomposition, and the species involved in this process have been revised and listed by different authors (Lefebvre and Gaudry 2009; Smith 1986) but it is evident that the main driver is the availability of water in/on the body tissues. Flies (Diptera) are the first colonizers, followed by beetles (Coleoptera), mites (Arachnida, Acarina) and then moths (Lepidoptera).

Whereas fly larvae need a wet substratum for food intake, some species of Coleoptera and the clothes moths are able to ingest and digest dry tissues. For this reason, a first triage based on the occurrence of the species on the body can be easily used to distinguish between insects active at the beginning of the decomposition of a body and insects arriving on the later waves of colonization and also a long time after the death, depending on the storage conditions. 


\section{Kind and state of preservation of the specimens}

The observation, via stereomicroscope of the developmental stage and the state of the preservation of the specimens, can also be useful and diriment. It has been already highlighted that different taxa survive to the time in a different way, with Coleoptera being more resistant than Diptera, at least at the adult stage. In contrast, looking at the immatures, especially puparia, they survive in Diptera and not in other taxonomical groups. In addition, some trace as frass (excrements) and complete exuviae are quite fragile and they can be recorded only if quite recent, whereas they are partially or completely destroyed with the time due to the feeding activity of other arthropods as well as because of physical traumas and bacterial or fungi action. Indeed, in case of Dermestes Linnaeus, 1758 only larva cephalic capsules and last segments with urogomphi are found from archaeological contexts, whereas complete larvae can be recorded from modern cases. In other species of the Dermestidae family, only larvae cephalic capsules and fragments of the cuticule (exuvia) are found from archaeological contexts, not fragmented exuviae are usually found in modern cases. Depending on the order, the informative elements to be checked to distinguish between MI and AI are summarized in Table 2.

\section{Temporal approach}

In some cases, an interesting and useful approach to the interpretation of the insects collected from archaeological sites and collections is based on the species distribution and on their time of appearance in a specific geographical context. This approach is of particular importance when dealing with human-introduced species, as for example associated with food that represents a good fraction of the species normally found also on human remains. In fact, if from one hand the discovery of a species in a specific context may be helpful in understanding the spreading/migrations of human populations (lice to trace human migration) or of their trades, invasions and colonisations (e.g. Manachini (2015)), from the other side it could be useful to understand if they were present at the collection time or they colonized the items only after their storage in the museum. The finding of a species not typical of the region from where the bones come from is a clear evidence that the colonization happened after their location in the museum collection.

\section{Food specificity}

There are some examples where the entomological records are not ecologically associated with the object of attention (Zangheri and Fontana 2000). For example, some specimens of the ptinid Oligomerus Redtenbacher, 1849 (Coleoptera, Ptinidae, Anobiinae) were found among the bones of Saint Mercuriale. However, they were not associated with the bones per se but with the wood of the coffin where the bones were stored as demonstrated by the holes present in the coffin, resulting from the emerging of the adult of the species.

\section{$C_{14}$ dating}

Panagiotakopulu (2003) suggested carbon dating as a reliable method to distinguish between archaeological and modern elements. The only limitation to this method could be the amount of material required to perform this kind of analysis. Despite the minimum amount of chitin can be of about 10-50 mg, a single puparium does not reach this weight. For this reason, a pool of elements has to be analysed. We recommend any way of working with a homogenous sample in order to avoid any error in considering different taxa with different access times to the human remains.

\section{Conclusion}

Taking into account that the work aims at distinguishing between initial insect colonizers of decomposing bodies and osteological collection pests, this paper provides a guideline useful in the differentiation between AI and MI. However, it also highlights the need of good experience in the field, as well as how the forensic entomology and funerary archaeoentomology represent a communicating vessels system.

Table 2 Main taxa collected from osteological collections

\begin{tabular}{|c|c|c|}
\hline & Archaeological interest (AI) & Museum pest insects (MI) \\
\hline Diptera & Puparia, fragment of adults (mainly head and thorax) & Absent \\
\hline Coleoptera & $\begin{array}{l}\text { Whole adults or part of them, dry larvae, in Dermestes often } \\
\text { present only the last segment with the urogomphi, in others only } \\
\text { the cephalic capsule, fragmented exuviae }\end{array}$ & $\begin{array}{l}\text { Complete, not altered exuviae, living adults and larvae } \\
\text { Sometimes pupal chambers still active, well detectable }\end{array}$ \\
\hline Lepidoptera & Empty cocoons, often partially degraded & $\begin{array}{l}\text { Cocoons, living or dead moths sometimes present, especially } \\
\text { in confined places }\end{array}$ \\
\hline Hymenoptera & Adult fragments (e.g. ant head, wasp head or abdomen terga) & Sometimes mud nest present among the osteological samples \\
\hline
\end{tabular}


Only the use of a modern reference collection may allow correct identification and interpretation of specimens from archaeological excavations or museal osteological collections. Unfortunately, due to the reductionistic mentality still operating in many fields of the high education sector and more in general in our society, the barrier between forensic and archaeoentomology is difficult to be bypassed. Of course, the two disciplines differ in term of aims but not in terms of procedures and general knowledge. The level of information that one discipline may offer to the other and vice versa is huge and fundamental for better integration of the data and understanding of the perimortem events. We have also to consider during life the corpse as a sort of ecosystem where microorganisms and other organisms may live in a commensal way. Also around and after death, the corpse has to be considered as a unit in relation with the environment and hosting some organisms for a short or long period of time. In addition, some courses of conservation focus only on insects as pest not considering the potential information that they carry. So, an integrated approach is the only one able to explain the complexity of the relationships between insects and human remains allowing a better understanding of the perimortem events and to design efficient conservation strategies.

Funding Open access funding provided by Università degli Studi di Genova within the CRUI-CARE Agreement.

Open Access This article is licensed under a Creative Commons Attribution 4.0 International License, which permits use, sharing, adaptation, distribution and reproduction in any medium or format, as long as you give appropriate credit to the original author(s) and the source, provide a link to the Creative Commons licence, and indicate if changes were made. The images or other third party material in this article are included in the article's Creative Commons licence, unless indicated otherwise in a credit line to the material. If material is not included in the article's Creative Commons licence and your intended use is not permitted by statutory regulation or exceeds the permitted use, you will need to obtain permission directly from the copyright holder. To view a copy of this licence, visit http://creativecommons.org/licenses/by/4.0/.

\section{References}

Belcastro M, Bonfiglioli B, Pedrosi M, Zuppello M, Tanganelli V, Mariotti V (2017) The history and composition of the identified human skeletal collection of the Certosa cemetery (Bologna, Italy, 19th-20th Century). Int J Osteoarchaeol 27:912-925. https://doi.org/10.1002/oa.2605

Forbes V, Bain A, Gísladóttir GA, Milek KB (2010) Reconstructing aspects of the daily life in late 19th and early 20th-century Iceland: archaeoentomological analysis of the Vatnsfjörður farm, NW Iceland. Archaeologia Islandica 8:77-110

Forbes V, Ledger PM, Cretu D, Elias S (2020) A sub-centennial, Little Ice Age climate reconstruction using beetle subfossil data from Nunalleq, southwestern Alaska. Quatern Int 549:118-129. https:// doi.org/10.1016/j.quaint.2019.07.011

Giordani G, Erauw C, Eeckhout P, Owens LS, Vanin S (2020) Patterns of camelid sacrifice at the site of Pachacamac, Peruvian Central Coast, during the Late Intermediate Period (AD1000-1470): perspectives from funerary archaeoentomology. J Archaeol Sci 114:105065. https://doi.org/10.1016/j.jas.2019.105065
Giordani G, Grzywacz A, Vanin S (2019) Characterization and identification of puparia of Hydrotaea Robineau-Desvoidy, 1830 (Diptera: Muscidae) from forensic and archaeological contexts. J Med Entomol 56:45-54. https://doi.org/10.1093/jme/tjy 142

Halmschlager E, Ladner C, Zabransky P, Schopf A (2007) First record of the wood boring weevil, Pentarthrum huttoni, in Austria (Coleoptera: Curculionidae). J Pest Sci 80:59-61. https://doi.org/ 10.1007/s10340-006-0148-3

Huchet JB (1996) L’Archéoentomologie funéraire: une approche originale dans l'interprétation des sépultures. Bull Mem Soc Anthropol Paris 3-4:299-311

Huchet JB (2013a) L'archéo-entomologie: les insectes nécrophages associés aux soldats de Carspach. In: Schnitzler B, Landolt M (eds) A l'est du nouveau! Archéologie de la Grande Guerre en Alsace et en Lorraine. Musée de Strasbourg, collection Archéologie, Strasbourg 109-110

Huchet JB (2013b) Les insectes de la tombe 40: archéoentomologie d'une urne funéraire. In: Andringa W.V. DH, Lepetz S., et al. (ed) Mourir à Pompéi - Fouille d'un quartier funéraire de la nécropole romaine de Porta Nocera (2003-2007), vol II - Artefacts et ecofacts en contexte funéraire. Ecole Française de Rome,

Huchet JB, Callou C, Lichtenberg R, Dunand F (2013) The dog mummy, the ticks and the louse fly: archaeological report of severe ectoparasitosis in Ancient Egypt. Int J Paleopathol 3:165175. https://doi.org/10.1016/j.ijpp.2013.07.001

Huchet JB, Greenberg B (2010) Flies, Mochicas and burial practices: a case study from Huaca de la Luna, Peru. J Archaeol Sci 37:28462856. https://doi.org/10.1016/j.jas.2010.06.025

Lefebvre F, Gaudry E (2009) Forensic entomology: a new hypothesis for the chronological succession pattern of necrophagous insect on human corpses. In: Annales de la Société entomologique de France 45(3):377-392

Manachini B (2015) Alien insect impact on cultural heritage and landscape: An underestimated problem. Conservation Science in Cultural Heritage 15:61-72. https://doi.org/10.6092/issn.1973-9494/7119

Mégnin J-P (1894) La Faune des Cadavres: Application de l'Entomologie à la Médecine Légale. G. Masson, Paris

Morrow J, Taylor L, Peck L, Elowsky C, Stewart Owens L, Eeckhout P, Reinhard K (2017) Pseudoscorpions of the family Cheiridiidae (Arachnida: Pseudoscorpiones) recovered from burial sediments at Pachacamac (500-1,500CE), Perú. J Arachnol 45:370-375. https://doi.org/10.1636/JoA-S-17-007.1

Panagiotakopulu E (2003) Insect remains from the collections in the Egyptian Museum of Turin. Archaeometry 45:355-362. https:// doi.org/10.1111/1475-4754.00113

Peacock ER (1993) Adults and larvae of Hide, Larder and Carpet Beetles and their relatives (Coleoptera: Dermestidae) and of Derodontid Beetles (Coleoptera: Derodontidae). Handbooks for the identifications of British insects, 5(3) 144

Skidmore P (1985) The biology of the Muscidae of the world. Springer, Netherlands, Dordrecht

Smith KGV (1986) A manual of forensic entomology. Cornell University Press, Ithaca

Vanin S (2019) Osservazioni sul materiale entomologico prelevato dal sarcofago di mummia. In: Zanasi C (ed) Storie d'Egitto. La riscoperta della raccolta egiziana del Museo Civico di Modena. All'Insegna del Giglio, Firenze, pp 90-91

Zangheri S, Fontana P (2000) Indagini sugli insetti rinvenuti nella bara attribuita a San Luca Evangelista. In: V. TWM, B. TFG (eds) I risultati scientifici sulla ricognizione delle reliquie attribuite a san Luca. Fonti e ricerche di Storia Ecclesiatica padovana, XXIXI: 669-678., Padova, 16-21

Publisher's note Springer Nature remains neutral with regard to jurisdictional claims in published maps and institutional affiliations. 